\title{
TMAGES OF 19TH CENTURY SWEDEN AND NORWAY IN THE WORKS GÖSTA BERLING'S SAGA BY SELMA LAGERLÖF AND CHILDREN OF THE AGE BY KNUT HAMSUN
}

\section{Crina Leon}

Alexandru Ioan Cuza University of Iasi, Email: crina_laurentiu@yahoo.no

\section{Acknowledgements}

This paper was presented at the Sixth international conference on Baltic and Nordic Studies in Romania Historical memory, the politics of memory and cultural identity: Romania, Scandinavia and the Baltic Sea Region in comparison, hosted by the Romanian Association for Baltic and Nordic Studies and Ovidius University of Constanța, May 22-23, 2015. Supported by EEA Grants, contract no 4/22.07.2014.

\section{Abstract:}

The present paper tries to depict how Sweden and Norway were represented in the novels Gösta Berling's Saga (1891) and Children of the Age (1913) written by the two Scandinavian Nobel Prize laureates, Selma Lagerlöf and Knut Hamsun, respectively. We will especially focus on the regions Värmland (in west central Sweden) and Nordland (in northern Norway). These two counties represent in fact the areas where Lagerlöf and Hamsun grew up and which they knew very well. Lagerlöf's story renders an area of mansion houses and ironworks from 1820, while Hamsun's novel dealing with the Segelfoss estate at a moment around 1870 depicts a society in change from old practices to modern times. Despite some supernatural elements in Gösta Berling's Saga, the two novels contribute to a geographical, social and economic identification with the regions under consideration. We thus find ourselves in front of two concentrated areas which resemble the real ones although the writing style of the authors is quite different, namely a neo-romantic way of writing with Lagerlöf versus Norwegian new realism with Hamsun. 


\section{Rezumat:}

Lucrarea de față încearcă să descrie modul în care au fost reprezentate Suedia şi Norvegia în romanele Povestea lui Gösta Berling (1891) şi Copii ai timpului lor (1913), romane ce apartin celor doi laureați scandinavi ai Premiului Nobel, Selma Lagerlöf şi respectiv Knut Hamsun. Ne vom concentra în special pe regiunile Värmland (în partea central vestică a Suediei) şi Nordland (în nordul Norvegiei). Aceste două provincii reprezintă, de fapt, zonele în care au crescut Lagerlöf şi Hamsun şi pe care aceştia le cunoşteau foarte bine. Povestea lui Lagerlöf redă o zonă de conace şi de prelucrare a fierului de la 1820, in timp ce romanul lui Hamsun despre proprietatea Segelfoss în jurul anului 1870 descrie o societate $\hat{\imath}$ schimbare de la practicile vechi la timpurile moderne. In ciuda unor elemente supranaturale din Povestea lui Gösta Berling, cele două romane contribuie la o identificare geografică, economică şi socială cu regiunile în discuție. Ne aflăm astfel în fața a două zone concentrate care se aseamănă cu cele reale, deşi stilul de scriere al autorilor este destul de diferit, şi anume o manieră neoromantică de scriere la Lagerlöf față de noul realism norvegian la Hamsun.

Keywords: $19^{\text {th }}$ century, Scandinavian literature, Selma Lagerlöf, Knut Hamsun, identity

\section{Introduction}

The novels Gösta Berling's Saga (1891) and Children of the Age (1913) deal with the childhood areas and landscapes of their writers, namely Selma Lagerlöf's Värmland in west central Sweden and Knut Hamsun's Nordland in northern Norway. What is common to these two works is the approach to the above-mentioned Scandinavian areas in the $19^{\text {th }}$ century. However, the two Nobel Prize laureates chose different ways of rendering the images to the readers. Gösta Berling's Saga is Lagerlöf's debut novel written in a decade characterized by neo-romanticism and appears as an opposition to the previous realism and naturalism. On the other hand, Knut Hamsun moves with Children of the Age from the neo-romanticism of the late $19^{\text {th }}$ century to the Norwegian new realism obvious in the later Nordland novels. "Hamsun is not the usual writer of one's place of origin, but he also had a home and a place from where he got his raw material. All art, also the great, also the greatest, has a starting point"1 [our translation],

\footnotetext{
1 Nils Magne Knutsen, Knut Hamsun og Norland. Den lange veien hjem (Tromsø: Angelica Forlag, 2006), 11. “Hamsun er ingen vanlig heimstaddikter, men også han hadde et hjemsted og et sted der han hentet sitt råstoff. All kunst, også den store, også den største, har et utgangpunkt."
} 
wrote Nils Magne Knutsen. The same could apply to Lagerlöf and her Värmland. Both authors were deeply rooted in their childhood regions not only as writers, but also as persons. But while Selma Lagerlöf focuses mainly on descriptions of nature, Knut Hamsun describes above all the development of the society in the second half of the $19^{\text {th }}$ century.

\section{The $19^{\text {th }}$ century Sweden in a neo-romantic approach}

Gösta Berling's Saga is in fact a collection of stories about the adventures of twelve cavaliers led by Gösta, a handsome, tall, young and defrocked minister. One of his flaws was too much drinking, which led to an ignorance of his duties although in the period taken into consideration, around the year 1820, people were quite tolerant of drinking. Gösta was "the cavalier of cavaliers, who alone was a greater speaker, singer, musician, hunter, drinker and player than all the others together. He had all the virtues of a true cavalier"2 [our translation], and moreover, he was "master of ten thousand kisses and thirteen thousand love letters" 3 [our translation]. Beautiful and rich women had loved him, but all he cared about was dancing, playing and drinking as in the case of a Nietzschean Dionysus.

In reality, Värmland "can in many ways be looked upon as a border region in terms of its physical and cultural geography [...] The topography changes from low plains around Lake Vänern in the south to hilly country toward the north. The land is incised by a number of north-south-running rift valleys, such as Klarälvsdalen, Fryksdalen, and Glafsfjorden [...] Climatic conditions also vary: the northern part, for example, is snowcovered nearly one hundred days more than the south. " 4 Lagerlöf also tells how beyond Fryksdalen with its rich and lively community of Värmlanders, there are the everlasting forests of the Finns (Finnskogen). Moreover, she describes the region in different moments of the year. Thus, in winter "the snow gleamed like the eyes of young girls, when the first

\footnotetext{
2 Selma Lagerlöf, Gösta Berlings saga, oversatt av O. Thommesen (Oslo: Gyldendal Norsk Forlag, 1993), 30. “kavalerenes kavaler, som alene var en større taler, sanger, musiker, jeger, drikkebror og spiller enn alle de andre tilsammen. Han hadde alle en kavalers dyder."

3 Ibid., 124. "herre til ti tusen kyss og tretten tusen kjærlighetsbrev."

4 Gabriel Bladh, "Selma Lagerlöf's Värmland: A Swedish Landskap in Thought and Practice," in Nordic Landscapes: Region and Belonging on the Northern Edge of Europe, edited by Michael Jones and Kenneth R. Olwig (Minneapolis: University of Minnesota Press, 2008), 224-225.
} 
waltz is played. Birches stretched their delicate web of thin, brownish red twigs against the clouds, and on some of them there sat a fringe of tiny sparkling ice needles" 5 [our translation]. Midsummer is "the finest time of the year [...] the defeat of darkness." 6 [our translation] People were going to church on this holy day dressed in beautiful clothes. "Never have I heard the lark sing so beautifully as in this area"7 [our translation]. In August "Lake Löven was clear as crystal. Mist lay over the mountains, and the air had become cool." 8 [our translation]

In the very end of the novel Lagerlöf writes that "The huge bees of fantasy have swarmed around us for ages, but how they will get into the hive of reality, it is their own business"9 [our translation], and through fantasy Lagerlöf succeeds in making us experience a piece of Sweden she knew very well. The school teacher Selma Lagerlöf teaches us a lesson about Sweden, although she sometimes prefers to replace reality, as it happens in the case of Lake Löven of the historical province of Värmland, which lies in the centre of the story and which is in fact the Fryken chain of lakes in Sweden. From the beginning of the book we find out that "Lake Löven is a long, narrow lake in Värmland [...]. It extends north up to the Forests of the Finns, in the south down towards Lake Vänern. Several villages spread out on its shores, but the parish Bro is the biggest and richest [...] on the left lie the largest farms, manor houses such as Ekeby and Björne, widely famous for their richness and beauty, as well as the big village of Broby with its inn, courthouse, sheriff's office, vicarage and market place."10 [our translation] After the whole series of adventures "Björne is still there, Ekeby is still on the shore of Lake Löven, magnificently surrounded by forest and sea, parks and smiling

\footnotetext{
${ }^{5}$ Lagerlöf, Gösta Berlings saga, 103. “sneen glimtet som unge pikeøyne, når det spilles opp til første vals. Bjerkene strakte sitt fine spinn av tynne, brunrøde kvister mot sky, og på en del av dem satt en frynse av små glitrende isnåler."

${ }^{6}$ Ibid., 204. "årets herligste tid [...] mørkets nederlag."

7 Ibid. "Aldri har jeg hørt lerken synge som over disse vidder."

8 Ibid., 235. "Löven lå speilklar. Soldisen lå over fjellene, og luften var blitt sval."

9 Ibid., 319. "Fantasiens kjempebier svermet om oss i år og dager, men hvordan de skal komme inn i virkelighetens kube, det får sandelig bli deres egen sak."

10 Ibid., 13. "Löven er en lang, smal sjø i Värmland [...]. Den strekker seg i nord opp mot finnskogene, i sør ned mot Vänern. Flere bygder brer seg ut på strendene, men Bro sogn er størst og rikest [...] på den venstre ligger de største gårdene, herreseter som Ekeby og Björne, vidt berømt for rikdom og skjønnhet, samt Brobys store grend med gjestgivergård, tinghus, lensmannsbolig, prestegård og markedsplass."
} 
meadows." 11 [our translation] We also find out that "Beyond Lake Löven lies Vänern. Beyond Lake Vänern lies the sea, everywhere endless plateaus of clear, blue-black ice."12 [our translation] Beside the details regarding the landscape the author also reveals characteristics of the Swedish life and people in Värmland, and the landscape seems to have influenced the regional identity: "the long lake, the rich fields and the blue mountains formed the most beautiful landscape and still do, and the people are also nowadays strong, brave and talented. Now great progress has also been made both in prosperity and enlightenment."13 [our translation]

The region of Värmland was famous for its timber, coal and ore. In spring, the iron from the ironworks was supposed to be sent to the big merchants in Gothenburg, lying on the west coast of Sweden. The contracts had been signed with the Mistress of Ekeby, once the most powerful woman in Värmland, the owner of seven forges, who had offered the cavaliers shelter and a life of pleasures at her manor house. But Ekeby, where the biggest ironwork in Värmland once was, no longer had iron because of the cavaliers, since all they had cared about was beer, wine and liquor, singing or playing cards. Moreover, dancing never stopped. Iron was also made in Strömme, Sölje, Kymsberg, Uddeholm or Munkfors. When Gösta went to talk with the managers of the other six ironworks, an unsuccessful journey, since none had iron, Lagerlöf continues with the description of the area: "he travelled a few miles northwards, until he reached Lötafors. It is a beautiful place, no doubt about it. Upper Löven spreads in front of it, and just behind there lies the Gurlita Cliff with its sharp-pointed top and a piece of wildness and romance, which is very suitable to an old mountain"14; "He goes further north to Björnidet. This is also a beautiful and magnificent place with a location that would be perfect for a castle. The large main building dominates a semicircular valley

\footnotetext{
11 Ibid., 319. "ennu står Björne, ennu ligger Ekeby ved Löven, herlig omkranset av skog og sjø, park og smilende enger."

12 Ibid., 125. "Bortenfor Löven ligger Vänern. Bortenfor Vänern ligger havet, overalt uendelige vidder av klar, blåsvart is."

13 Ibid., 27. "den lange sjøen, den rike sletten og de blå fjellene, dannet det vakreste landskap og gjør det ennu, og folket er også idag kraftig, modig og vel begavet. Nu har det også gjort store fremskritt både i velstand og opplysning."

14 Ibid., 188. "han reiste et par mil nordover, til han nådde Lötafors. Det er et vakkert sted, ingen tvil om det. Övre Löven brer seg foran det, og like bak seg har det Gurlitafjellet med sin spisse topp og et stykke villhet og romantikk, som passer seg godt for et gammelt fjell."
} 
surrounded by mighty heights on three sides and on the fourth by Löven, which has its endpoint there."15; "Then Gösta heads south again. He comes to Hån, on the eastern shore of Löven, and to Lövstafors deep in the forests." 16 [our translation] The iron needed to be "loaded onto barges on the banks of Klarälvsdalen, ready to dash down the river, ready to be weighed on the iron scale in Karlstad, ready to be carried on a ship on the Lake Vänern to Gothenburg." 17 [our translation] Given this journey, we find out for instance that in the area there was only one carpenter who knew how to repair the forge wheel and that the coal burners and bearers had not been paid from Ekeby, which led to the absence of work the whole winter. The economic situation of the region depended in fact to a large extent on the commerce with iron and wood. When iron production developed, peasants were also involved in different activities related to mining, and the population grew near the ironworks. Thus these ironworks played an important role in the province with the exception of the plains around Lake Vänern, the largest lake in Sweden.

Poetical language and legend are intertwined in the pages of the novel and the first person narrative is used to describe memories of the inhabitants of the area in a continuous dialogue with the reader: "I have nothing new to tell you, only what is old and almost forgotten"18 [our translation], “Oh, Värmland [...] my beautiful, my magnificent Värmland! Often, when I have seen you before me on a map, I have wondered what you really represent [...] Wide forests are your dress. Long bands of blue water and uniform rows of blue hills border it [...] You sit quietly while the waves of Lake Vänern wash your feet and your crossed legs. To the left you have your fields of ore and mines. There is your beating heart. To the north you have the dark of wilderness and secrecy, beautiful regions. There is your dreaming head." 19 [our translation] These are the words uttered by

\footnotetext{
15 Ibid., 189. “Han drar videre nordover til Björnidet. Også det er et vakkert og prektig sted med en beliggenhet som ville gjøre et slott ære. Den store hovedbygningen behersker en halvrund dal, som er omgitt av veldige høyder på tre kanter og på den fjerde av Löven, som har sitt endepunkt der."

16 Ibid. "Så styrer Gösta sørover igjen. Han kommer til Hån på Lövens østbredd, og til Lövstafors langt inne i skogene."

17 Ibid. "lastet på prammer ved Klaraelvens bredd, ferdig til å stryke nedover elven, ferdig til å veies på jernvekten i Karlstad, ferdig til å føres på en Vänerskute til Göteborg."

18 Ibid., 131. "Jeg har ikke noe nytt å fortelle dere, bare det som er gammelt og nesten glemt." 19 Ibid., 219. “Å, Värmland [...] du skjønne, du herlige! Ofte, når jeg har sett deg for meg på et kart, har jeg undret meg på hva du egentlig forestiller [...] Vide skoger er din klesdrakt.
} 
Squire Julius, one of the twelve cavaliers, but which express the writer's strong relationship with her native area.

Lagerlöf makes also use of supernatural elements such as in the case of Sintram, the mean owner of one of the forges, whose arrival was announced by bad spirits entering the people's houses, making noise, opening and closing doors. Sintram was the Devil that signed a pact with Gösta's blood, stating that the cavaliers were to rule over the forges for one year and live a life of pleasures. Only love could save Gösta. And he was saved by "an angel from heaven" 20 [our translation], the former wife of the count of Borg, a good and innocent woman whom he married. When the Mistress of Ekeby came back on Christmas Eve, she learnt that Gösta was now helping the people, that the cavaliers were working hard, that the mill and the forge were again operational and Ekeby could thus regain its glory.

\section{$19^{\text {th }}$ century Norway depicted through new realism}

The region of Nordland had been depicted in several of Knut Hamsun's works such as Pan (1894), Siesta (1897), In Wonderland (1903), Benoni og Rosa (1908), The Last Joy (1912) before the old and modern times in Northern Norway met in Hamsun's novel Children of the Age in 1913. This was the first of the double novel about Segelfoss, and it was followed by Segelfoss Town (1915). From the very beginning of the novel we are introduced into the world of the Segelfoss estate in Nordland. "The entire neighborhood was once one property, and what is now the Segelfoss farm was the main centre. Segelfoss was then according to Nordland terms a whole estate of about fifty cows. Moreover, it had a saw, a mill, a brickyard and extended areas of woods. There was great life on the farm, with servants and smallholders and idlers; there were also animals in abundance beside the many cattle: horses and dogs, cats and pigs and along the back side of the barn there was plenty of place for hens and geese." 21

Lange bånd av blått vann og jevntløpende rader av blå koller kanter det [...] Du sitter stille mens Vänerns bølger vasker dine føtter og dine korslagte ben. Til venstre har du dine malmfelter og gruber. Der er ditt bankende hjerte. Mot nord har du ødets, hemmelighetens mørke, vakre trakter. Der er ditt drømmende hode."

20 Ibid., 279. "en engel fra himmelen."

${ }^{21}$ Knut Hamsun, Børn av tiden (Oslo: Gyldendal Norsk Forlag, 1994), 7. "Hele grænden var én eiendom engang, og det som nu er gården Segelfoss var hovedsætet. Da var Segelfoss efter nordlandske forhold et helt gods på halvhundrede kjyr, desuten hadde det sag, kværnbruk, teglværk og mange mil skog. Det var et stort liv på gården av tjenestefolk og 
Willatz Holmsen III, called the "lieutenant", was the owner of the Segelfoss estate. He is the representative of old times, ruling with authority, but also helping others in matters of work or education. He "had smallholders and tenant farmers from the mountain to the beach, and rode down to the fishermen by the sea [...] The lieutenant was by no means heartless, sometimes he helped a girl to became a servant on the estate, sometimes he sent potatoes and pork to families who were in need." 22 [our translation] He had inherited a debt from his father, and his sisters and mother had gone to live in Sweden: "his sisters whom he had not seen since they became so Swedish - and his mother who could not live in poverty, but left [...] She had indeed abandoned like a rat a ship which did not sink." ${ }^{23}$ [our translation] Holmsen was married to the daughter of a German colonel and did not have a very good relationship with his wife, Adelheid. Mrs. Holmsen had grown up in Denmark, and now felt quite isolated at Segelfoss, with little social life, and trying to keep in contact with her native country through newspapers and letters. In Norway she used to ride, sing or paint. Moreover, she was fond of the church they had on the estate and since the old church was in a bad condition, a new church later donated to the parish was built with own funds and own workers on the private property of the Holmsens. Here they also had their son Willatz Holmsen IV christened. Otherwise, they would have had to have him christened in Trondhjem, the most important city in Central Norway.

Hamsun also tells his readers about the social layers in Norway. The country did not have a proper aristocracy, but in a way the clerks behaved as a sort of aristocracy. Their sons had to become in their turn clerks while their daughters were compelled to marry other clerks. The period described is the 1870s after the Franco-German War of 1870-1871 mentioned as well in the text. At Segelfoss the people at that time were either fishermen or worked in the forest, but transformations began to take place, and these are representative of the development of the society in the

\footnotetext{
husmænd og lediggiængere, det var også dyr i overflod, foruten den store buskap hester og hunder, katter og griser og langs hele baksiden av låven var en by for høner og gjæss."

22 Ibid., 22. "Han hadde husmænd og leilændinger fra fjæld til fjære og ridde like ned til fiskerne ved sjøen [...] Løitnanten var ingenlunde uten hjærte, stundom hjalp han en pike til tjeneste på godset, stundom sendte han potet og flæsk til en familje som var i trang."

${ }^{23}$ Ibid., 14. "hans søstre som han ikke hadde set siden de blev så svenske - og hans mor som ikke kunde leve i misère, men var reist [...] Hun hadde sandelig som en rotte forlatt et skib som ikke sank."
} 
second half of the 19th century: "now the decline began. The Lieutenant could be close-fisted enough, but things went slowly backwards with him and the estate; he ran both the farm and the brickyard as before, yes much better than before, but times changed, this was no longer worthwhile. He neglected the mill, the dam which his poor father had wanted to repair and expand finally collapsed and the lieutenant did not build it up again. He took his own flour from Bergen." 24 [our translation]

As a counterpart to Holmsen, who behaves according to old norms, Hamsun introduces the character Tobias Holmengrå. The rich man coming back home from Mexico appears as a representative of the new era, the one who will begin to develop industry at Segelfoss. "A houseboat came rowing [...] The boat came alongside a little bit up the river mouth, at the brickyard. A big fat man crept out of the houseboat in a fur coat and a large rainwear [...] the boat was not known either and must have come from far away." 25 [our translation] Holmengrå had been away for 30 years, but still kept the memory of the symbol of Segelfoss. Thus he asserts: "I sit and think about where I am. In my childhood Segelfoss was the biggest place we heard about there, on the coast. I did not even dream that I would once sit here in the living room." 26 [our translation] The view from Segelfoss impresses him: "what a view from here, the sea and large forests, fields and meadows. And then the river. And then the church out there." 27 [our translation]

Holmengrå himself notices that Norway has undergone changes, since people now had bigger houses, more children, and the growth of the population has also intensified the agricultural activities. On the other hand, he adds that "I think that here northwards, the progress is least significant. New people have grown up here, but they resemble so

24 Ibid., 10. "nu begyndte forfaldet. Løitnanten kunde være påholdende nok, men det gik langsomt bakover med ham og godset, han drev både gården og teglværket som før, ja meget bedre end før, men tiderne skiftet, det lønnet sig ikke mere. Kværnen lot han helt stå, dammen som hans salig far hadde villet gjøre istand og utvide var nu endelig raset ut og løitnanten fik ikke bygget den op igjen. Sit eget mel tok han fra Bergen."

25 Ibid., 27. "Det kom en husbåt roende [...] Båten la til litt oppe i elvemundingen, ved teglværket. Ut av båthuset krøp en stor tyk mand i pels og svært hyre [...] båten var heller ikke kjendt og måtte høre til længere borte."

${ }^{26}$ Ibid., 33. "Jeg sitter og tænker på hvor jeg er. I min barndom var Segelfoss det største sted vi hørte om i ytterleia, jeg drømte minst at jeg skulde få sitte her i stuen engang."

${ }^{27}$ Ibid., 34. "for en utsigt herfra, hav og store skoger, marker og enger. Og så elven. Og så kirken derute." 
strangely the old, they go with their hands in the pockets, they are natives of Nordland." 28 [our translation] Holmengrå tells how he had to look fat and rich so that the inhabitants should recognize him according to the stories they had heard: "When I should have rowers, I could get none. They stood there in Henriksen's store and walked about on the wharf with their hands in the pockets. They wanted to sail, but there was no wind, and they did not want to row. I recognized again my countrymen" 29 [our translation] or "I knew that if there is something which impresses the natives of Nordland, then that is diameter and grand clothes and tinsel." 30 [our translation]

The conflict between old and new becomes nevertheless more and more evident. This is reflected for instance in the fact that the son Willatz is sent to England to study, and does not study at home with a teacher as it traditionally happened. Also, when their friends, the Coldevins, visit the Holmsens, the young Coldevin, who was a merchant on the western coast, agrees that "There are modern times [...] These large farms are not worthwhile, they just wear out the owner's forces. They can be for those who traditionally have self-evident capitals to break into."31 [our translation] The generation gap is also obvious when the issue of money comes into discussion. The old Coldevin asks: "what if now we limited ourselves, your mother and I, what if we sold everything away and got money and assets? Then we would have only some money to look at and not some big land."32 [our translation]

But Holmengrå is the one who changes the whole rhythm at Segelfoss. A new world appears in the meantime with focus on 'money' or 'competition', words more and more frequently used. People learn how to do business and how to obtain better prices: "The idea was so that when I

28 Ibid., 36. "Her nordover synes jeg fremskridtet er ringest. Her har vokset op nye mennesker, de likner så mærkelig de gamle, de går med hænderne i lommen, de er nordlændinger."

${ }^{29}$ Ibid., "Da jeg skulde ha skysskarer kunne jeg ingen få. De stod der på Henriksens krambod og drev omkring på hans brygge med hænderne i lommen. De vilde nok seile, men det var ikke vind, og ro vilde de ikke. Jeg kjendte mine folk igjen."

30 Ibid., 36-37. "Jeg visste jo at er det noget som imponerer nordlændingen så er det tykkelse og gromme klær og flitter."

31 Ibid., 51. "Det er den moderne tid [...] Disse store gårdene betaler sig ikke, de bare øder eierens kræfter. Det kan være for dem som fra gammel tid har oplagte kapitaler å tære på."

32 Ibid. "hvis vi nu gjorde os mindre, din mor og jeg, hvis vi solgte væk og fik penger og middel så hadde vi jo bare nogen penger å se på og ikke nogen stor jord." 
take the goods directly home from cereal countries it is not necessary that they go through another hand in Bergen and become more expensive." 33 [our translation] Little by little, "Segelfoss became a market, there was noise everywhere, shots in the hill, people and traffic on the roads. There landed sloops with timber and food, with stoves, wallpaper, furniture, sacks and boxes, large boxes; there came Swedes and offered themselves for work."34 [our translation] A shop was opened by the sea for Holmengrå's workers who needed food, tobacco, coffee and clothes.

By manipulating the lieutenant, Holmengrå bought more and more properties from him until Holmsen got to live in a mortgaged house on a mortgaged land: "He was tortured by his failure, but he could not stop it." 35 [our translation] Holmengrå was planning and managed to build a mill, an access road to the mill, an enterprise, a whole small town. Segelfoss became a post office and a stop for the ship route Vadsø-Hamburg. "I have certainly made these places much more restless than they were [...] this place is suitable for large traffic and business. It has a clean coast, deep water to the beach, timber in the forest, a river, a waterfall, a densely populated area, fields and meadows, an enormous grazing land." 36 [our translation] After a while, Holmengrå also fetched his two children, Mariane and Felix, from Mexico, while Willatz Holmsen IV continued his studies in England, where he also learned to dance, to play the piano and to swim. The social changes also refer to the use of names: "The son had thus grown a bit too fast in his letters and he had begun to sign his name Will. Why is that? The last letter to his mother was even signed Bill, was it the same as the good old Willatz? And should it perhaps end with the whole name becoming Bill Holmes as anyone was called? The lieutenant was the head of the dynasty Willatz Holmsen and he should steer it until the end of his life." 37 [our translation]

33 Ibid., 67. "Meningen var altså at når jeg tar godset direkte hjem fra kornlandene så behøver det ikke å gå gjennem anden hånd i Bergen og bli dyrere."

34 Ibid., 65. "Segelfoss blev et marked, det blev uro overalt, skudd i åsen, folk og færdsel på veiene. Der landet jægter med trælast og matvarer, med ovner, tapet, møbler, sækker og kasser, store kasser; der kom svensker og bydde sig til med arbeide."

35 Ibid., 141. "Han pintes av sin misère, men han kunde ikke stanse den."

36 Ibid., 78. "Jeg har riktignok gjort Deres sted meget uroligere end det var [...] dette sted er egnet til stor trafik og virksomhet? Det har ren kyst, en nærdyp strand, tømmer i skogen, elv, foss, et tætgrændt opland, akrer og enger, et uhyre utbeite."

37 Ibid., 97. "Sønnen hadde således vokset litt for fort i sine brever og han hadde begyndt å skrive sig Will. Hvorfor det? Siste brev til morn var endog underskrevet Bill, var det det 
Gradually, the population in the Segelfoss region grew and many more houses were built by the quay where the steamboats came: "the lower part of the Segelfoss property already began to be like a small town of cottages." 38 [our translation] Wheat came by boat from the Baltic and Black seas, was ground here owing to the local mill, and the flour turned white. And changes continued. Thus, we are also being told about the efforts to get a telegraph post. Later, when Mrs. Holmsen died in Berlin, the news came first by telegraph and then she was brought to Nordland by postal ship. "The postal ships which at the beginning had gone only every third week went by now every single week of the year, Bårdsen [...] telegraphed about herring and fish and purchases and sales and goods and business therefore it was indeed life at Segelfoss; but the atmosphere was gloomy." 39 [our translation] This happened because even if lacking monotony, modernity provides false values: "Modernity makes life easy for us, but at the same time makes us dissatisfied and restless and excited, it causes us to lose the peace of mind that is the real basis for happiness." 40 [our translation] For Hamsun it was easy to notice the real changes which had occurred in Nordland. He had lived in this area as a child and until he was 20 years old, then he paid a new visit in 1900, and in 1911 he moved again to Northern Norway where he remained until 1917.

\section{Conclusions}

By writing Gosta Berling's saga, Selma Lagerlöf "made a lasting contribution to the characteristic image of landskapet Värmland (here both the province and the landscape of Värmland). She connected the (hi)stories of the province with the geographical landscape and cast them into a romantic light that still shapes the images of Värmland and

samme som det gode gamle Willatz? Og skulde det kanske ende med at hele navnet blev Bill Holmes som enhver hette? Løitnanten var overhode for dynastiet Willatz Holmsen og skulde lede det sin tid ut."

38 Ibid., 105. "den nedre del av Segelfoss grund allerede begyndte å bli som en liten by av stuer."

39 Ibid., 176. "postskibene som først hadde gåt bare hver tredje uke gik nu hver eneste uke i året, Bårdsen [...] telegraferte om sild og fisk og kjøp og salg og varer og virksomhet - derfor var det liv nok på Segelfoss; men stemningen var dyster."

40 Knutsen, Knut Hamsun og Norland, 40. "Moderniteten gjør livet lettvint for oss, men samtidig gjør den oss utilfredse og rastløse og oppspilte, den får oss til å miste den ro i sjelen som er det egentlige grunnlag for lykke." 
Värmlanders"41. The province Värmland was an important iron-producing area in the first half of the 19th century before the process of industrialization began, and the heterogeneous landscape features fields, mountains and lakes. Moreover, the joyful and adventurous inhabitants complete the image of the province, which Lagerlöf renders in a neoromantic style.

On the other hand, so as to present the decline of the old rules of the society and the birth of modern times in Northern Norway, Hamsun chooses to move towards Norwegian new realism. In Children of the Age the social changes at the end of the 19th century are highlighted and we are witnesses to the beginning of a progress whose description will continue in Hamsun's following novel. Knut Hamsun wants to point out the threat of the modernization of his time. "What happens is a form of chain reaction: Changes in property relations lead to a change in the production relations, which again leads to a change in people's moral attitudes. It is on this last point Hamsun puts his sharpest criticism of industrialization." 42 [our translation]

\section{References}

\section{Books and articles}

Bladh, Gabriel. "Selma Lagerlöf's Värmland: A Swedish Landskap in Thought and Practice." In Nordic Landscapes: Region and Belonging on the Northern Edge of Europe, edited by Michael Jones and Kenneth R. Olwig, 220-250. Minneapolis: University of Minnesota Press, 2008. Forsås-Scott, Helena, Lisbeth Stenberg, and Bjarne Thorup-Thomsen, eds. Re-Mapping Lagerlöf: Performance, intermediality and European transmissions. Lund: Nordic Academic Press, 2014.

Gustafson, Alrik. Six Scandinavian Novelists: Lie, Jacobsen, Heidenstam, Selma

Lagerlöf, Hamsun, Sigrid Undset. New York: Biblo and Tannen, 1969. Hamsun, Knut. Børn av tiden. Oslo: Gyldendal Norsk Forlag, 1994. Knutsen, Nils Magne. Hamsun. Oslo: Aschehoug, 1975.

\footnotetext{
41 Bladh, "Selma Lagerlöf's Värmland", 220.

42 Knutsen, Knut Hamsun og Norland, 39. "Det som skjer, er en form for kjedereaksjon: Endring i eiendomsforholdene fører til en endring i produksjonsforholdene som igjen fører til en endring i folks moralske holdninger. Det er på dette siste punktet Hamsun setter inn sin skarpeste kritikk av industrialiseringa."
} 
104 | Revista Română de Studii Baltice și Nordice / The Romanian Journal for Baltic and Nordic Studies 7 (1)

Knutsen, Nils Magne. Knut Hamsun og Norland. Den lange veien hjem. Tromsø: Angelica Forlag, 2006.

Lagerlöf, Selma. Gösta Berlings saga. Oversatt av O. Thommesen. Oslo: Gyldendal Norsk Forlag, 1993.

Lyngstad, Sverre. Knut Hamsun, Novelist: A Critical Assessment. New York: Peter Lang Publishing, 2005. 